\title{
Gender, neighboring competition and habitat effects on the stem growth in dioecious Fraxinus mandshurica trees in a northern temperate forest
}

\author{
Chunyu Zhang, Xiuhai ZHAO*, Lushuang GAO, Klaus v. GAdOW \\ Key Laboratory for Silviculture and Conservation, the Ministry of Education, Beijing Forestry University, 100083, P.R. China
}

(Received 17 November 2008; accepted 15 April 2009)

Keywords:

causal model /

stem growth /

intrasexual competition /

sex ratio /

dioecious species

Mots-clés :

modèle causal /

croissance de la tige /

concurrence intra-sexuelle /

sex-ratio /

espèces dioïques

\begin{abstract}
- This study analyses the sex ratios, and the effect of gender, neighboring competition and habitat factors on the stem growth of dioecious F. mandshurica trees in the Changbai Mountains of NorthEastern China.

- The general sex ratio of the flowering trees did not significantly deviate from 1:1. The sex ratio varied among age classes. A female-biased sex ratio was found in the age classes of 65-75 years and 85-95 years, but departure from 1:1 was not significant in other age classes.

- An analysis of variance revealed that the growth rate was extremely sensitive to gender and tree size, as shown by a highly significant gender-related and size-dependent effect. Male trees had a faster stem growth rate than female trees, and the assumption is that trade-offs between reproductive and vegetative processes can induce the difference in stem growth rate between genders.

- Stem growth rates are positively affected by soil moisture and tree size for both genders at all considered neighborhood distances. The growth rates of female trees were negatively affected by neighboring competition from other female trees at all neighborhood distances between 1 and $10 \mathrm{~m}$, but were not significantly affected by male trees. The growth rates of male trees were negatively affected by neighboring competition from male trees for neighborhood distances between 3 and $10 \mathrm{~m}$, but were not significantly affected by female trees.

- These results suggest that intrasexual competition (male-male competition and female-female competition) may cause difference in stem growth for both genders. Intersexual differences in sensitivity to neighboring plants are considered to be an important factor driving gender-specific growth patterns.
\end{abstract}

Résumé - Genres, compétition des voisins et effets de l'habitat sur la croissance des tiges des arbres diö̈ques chez Fraxinus mandshurica dans une forêt tempérée du Nord-Est de la Chine. - Cette étude analyse le sex-ratio, et les effets du genre, de la compétition des voisins et des facteurs de l'habitat sur la croissance de la tige des arbres dioïques chez Fraxinus mandshurica dans les montagnes de Changbai dans le Nord-Est de la Chine.

- Le sex-ratio général de la floraison des arbres ne s'écartait pas de façon significative de 1:1. Le sex-ratio a varié entre les classes d'âge. Une tendance femelle du sex-ratio a été trouvée dans les classes d'âge 65-75 ans et 85-35 ans, mais l'exception 1:1 n'était pas significative dans les autres classes d'âge.

- Une analyse de variance a révélé que le taux de croissance était extrêmement sensible au genre et à la taille des arbres, démontré par une liaison significative avec le genre et des effets dépendants de la taille. Les arbres mâles avaient un taux de croissance de la tige plus rapide que celle des arbres femelles, et l'hypothèse est que des compromis entre processus reproductifs et processus végétatifs peuvent induire la différence dans les taux de croissance entre les genres.

- Les taux de croissance des tiges ont été positivement affectés par l'humidité du sol et la taille des arbres quelle que soit la distance des arbres voisins. Les taux de croissance des arbres femelles ont été négativement affectés par la concurrence des arbres voisins femelles quelque soit la distance entre 1 et 10 m, mais n'ont pas été significativement affectés par les arbres mâles. Les taux de croissance des arbres mâles ont été négativement affectés par la concurrence des arbres mâles voisins à des distances comprises entre 3 et $10 \mathrm{~m}$, mais ils n'ont pas été affectés par les arbres femelles.

\footnotetext{
*Corresponding author: bfuz@163.com
} 
- Ces résultats suggèrent que la concurrence intra-sexuelle (concurrence mâle-mâle et concurrence femelle-femelle) peut causer des différences dans la croissance des tiges pour les deux genres. Des différences intersexuelles dans la sensibilité aux plants voisins sont considérées comme étant un important facteur commandant les modèles spécifiques de croissance des genres.

\section{INTRODUCTION}

Differences in the growth of dioecious plants have been studied before, but it is difficult to assess the prevalence of dimorphism (Jing and Coley, 1990; Ramp and Stephenson, 1988). Most studies found that males are larger (Hoffman and Alliende, 1984; Vasiliauskas and Aarssen, 1992) and that males grow faster than females (Cipollini and Whigham, 1994; Jing and Coley, 1990; Luken, 1987). However, several studies have shown equal or greater vegetative growth in females (Bullock, 1992; Davidson and Remphrey, 1990; Grant and Mitton, 1979; Gross and Soulé, 1981; Houle and Duchesne, 1999; Marion and Houle, 1996; Nicotra, 1999; Onyekwelu and Harper, 1979; Putwain and Harper, 1972; Sakai and Burris, 1985; Sakai and Sharik, 1988; Vasiliauskas and Aarssen, 1992; Willson, 1986), despite greater reproductive allocation. Some studies revealed that gender-specific growth rates depended on plant reproductive status (Nicotra, 1999; Ramp and Stephenson, 1988) and environmental context (Dawson and Ehleringer, 1993).

It is generally assumed that female dioecious species allocate more resources to reproduction than males (Allen and Antos, 1988; Armstrong and Irvine, 1989; Barrett and Helenurm, 1981; Cipollini and Stiles, 1991; Delph, 1999; Korpelainen, 1992; Lloyd and Webb, 1977; Lovett Doust et al., 1987; Marion and Houle, 1996; Meagher and Antonovics, 1982; Obeso, 2002). The resulting greater reproductive cost in females is due to seed production (Antos and Allen, 1999; Gross and Soule, 1981; Kohorn, 1994; Lovett Doust and Lovett Doust, 1988; Nicotra, 1999; Obeso, 1997). Resource trade-off theory assumes that there is a resource trade-off in females between reproductive and vegetative allocation (Allen and Antos, 1993; Cipollini and Whigham, 1994; Houssard et al., 1994; Rocheleau and Houle, 2001). According to this theory, the reproductive investment can affect growth rates, which are assumed to be lower in the females than in the males (Allen and Antos, 1993; Antos and Allen, 1999; Cornelissen and Stiling, 2005; Delph, 1999; Garcia and Antor, 1995; Gehring and Linhart, 1993; Herrera, 1988; Lloyd and Webb, 1977; Lovett Doust and Lovett Doust, 1988; Lovett Doust et al., 1987; Popp and Reinartz, 1988; Ramadan et al., 1994; Vasiliauskas and Aarssen, 1992).

However, some of these differences might depend on the environment in which both genders develop (Retuerto et al., 2000). Thus, when assessing gender dimorphism greater account should be taken of gender-specific interactions with the environment. Growth may be primarily limited by habitat conditions, such as soil type, soil nutrient, moisture availability and light intensity (Bullock, 1992; Guillon and Fievet, 2003; Tryon and Pease, 1953). Gender-specific water use efficiency could play a decisive role in explaining gender-specific differences in growth and ecological interactions (Hill et al., 1996;
Retuerto et al., 2000). A number of studies have evaluated the effect of tree size on stem growth (Bullock, 1992; Lee et al., 2003), and plant size-effects are also important in explaining growth dynamics. Furthermore, the sexual difference in sensitivity to neighboring trees is strongly related with the stem growth of male and female trees (Nanami et al., 2005).

Thus, we can present the hypothesis that stem growth is gender-related and size-dependent for dioecious Fraxinus mandshurica trees, and that males have a greater stem growth rates than female trees because of lower reproductive costs. It was the aim of the present field study to test this hypothesis. The analysis was limited to the past 5 years, and we assume that local competition by neighboring trees and habitat conditions during this period remained unchanged. Specifically, we will examine two questions: (1) Are there significant differences in stem growth between genders and/or among tree sizes? (2) To what extent do habitat factors and local crowded conditions affect the stem growth rates of each sex?

\section{MATERIAL AND METHODS}

\subsection{Study sites}

The study area is located just outside the Changbai mountains Nature Reserve $\left(128^{\circ} 07^{\prime} 49^{\prime \prime} \mathrm{E}, 42^{\circ} 19^{\prime} 10^{\prime \prime} \mathrm{N}\right)$ at an altitude of $899 \mathrm{~m}$ above sea level. The site represents the typical forest type and landscape of deciduous broad-leaved and coniferous mixed forest in Northeastern China. The climate is described as continental monsoon with an average annual temperature of $3.6^{\circ} \mathrm{C}$ (January $-15.4{ }^{\circ} \mathrm{C}$ and July $19.6{ }^{\circ} \mathrm{C}$ ), an annual precipitation of $707 \mathrm{~mm} \mathrm{y}^{-1}$, and an annual relative humidity of $66 \%$. The parent material is granite bedrock and the soil is mostly a dark brown forest soil, with a depth ranging from 20 to $100 \mathrm{~cm}$. Slopes are generally less than five degrees.

\subsection{Field sampling and data collection}

A permanent research plot covering an area of $200 \mathrm{~m} \times 260 \mathrm{~m}$ $\left(5.2 \mathrm{hm}^{2}\right)$ was established in 2005 . The plot was subdivided into 130 contiguous $20 \mathrm{~m} \times 20 \mathrm{~m}$ square subplots. In each subplot, the species of all live and dead trees with woody stems exceeding $1 \mathrm{~cm}$ breast height diameter (dbh) were identified, spatially mapped to the nearest $0.1 \mathrm{~m}$ accuracy, and tagged. The dbh, height and crown diameter of each tree were measured and recorded. The study stand is a protected forest dominated by Betula platyphylla, Tilia amurensis, F. mandshurica and Populus daviana in association with other subcanopy tree species. Density characteristics of dominant tree species in research plot are shown in Table I. Spatial distribution of all live trees $>4 \mathrm{~cm}$ dbh and their canopy positions relative to F. mandshurica in 5.2-hm ${ }^{2}$ plot are shown in Figure 1.

Two hemispherical photographs were taken $1 \mathrm{~m}$ above the ground in each subplot with an advanced canopy analysis system 
Table I. Species composition, density, basal area and maximum diameter of live trees $>1 \mathrm{~cm}$ dbh measured in $5.2-\mathrm{hm}^{2}$ research plot in the Changbai Mountains of North China.

\begin{tabular}{|c|c|c|c|c|c|c|}
\hline Tree species & $\begin{array}{c}\text { Density } \\
\left(\text { No. }^{\left.-h^{-2}\right)}\right.\end{array}$ & $\begin{array}{c}\text { Percent of total } \\
\text { density }(\%)\end{array}$ & $\begin{array}{l}\text { Basal area } \\
\left(\mathrm{m}^{2} \mathrm{hm}^{-2}\right)\end{array}$ & $\begin{array}{l}\text { Percent of total } \\
\text { basal area }(\%)\end{array}$ & $\begin{array}{l}\text { Mean dbh } \\
(\mathrm{cm})\end{array}$ & $\begin{array}{l}\text { Maximum } \\
\text { dbh }(\mathrm{cm})\end{array}$ \\
\hline Fraxinus mandshurica & 148 & 3.67 & 3.22 & 13.02 & 13.11 & 58 \\
\hline Male trees & 25 & 0.62 & 1.34 & 5.42 & 24.5 & 58 \\
\hline Female trees & 30 & 0.74 & 1.52 & 6.14 & 24.9 & 43.6 \\
\hline Non-flowering trees & 94 & 2.33 & 0.36 & 1.46 & 7.7 & 33.9 \\
\hline Betula platyphylla & 141 & 3.5 & 3.69 & 14.92 & 16.82 & 38.5 \\
\hline Tilia amurensis & 436 & 10.82 & 3.58 & 14.47 & 7.57 & 51.1 \\
\hline Populus daviana & 342 & 8.49 & 3.03 & 12.25 & 6.51 & 43.4 \\
\hline Quercus mongolica & 140 & 3.47 & 1.49 & 6.02 & 8.78 & 47 \\
\hline Picea jezoensis & 98 & 2.43 & 1.46 & 5.9 & 11.03 & 43.2 \\
\hline Abies nephrolepis & 206 & 5.11 & 1.34 & 5.42 & 7.07 & 80 \\
\hline Ulmus var. japonica & 145 & 3.6 & 1.03 & 4.16 & 7.15 & 35 \\
\hline Pinus koraiensis & 84 & 2.08 & 0.99 & 4 & 9.3 & 41 \\
\hline Acer mono & 547 & 13.58 & 0.98 & 3.96 & 3.09 & 46.8 \\
\hline Others & 1741 & 43.21 & 3.93 & 15.89 & 4.2 & 105 \\
\hline Totals & 4029 & 100 & 24.74 & 100 & & \\
\hline
\end{tabular}

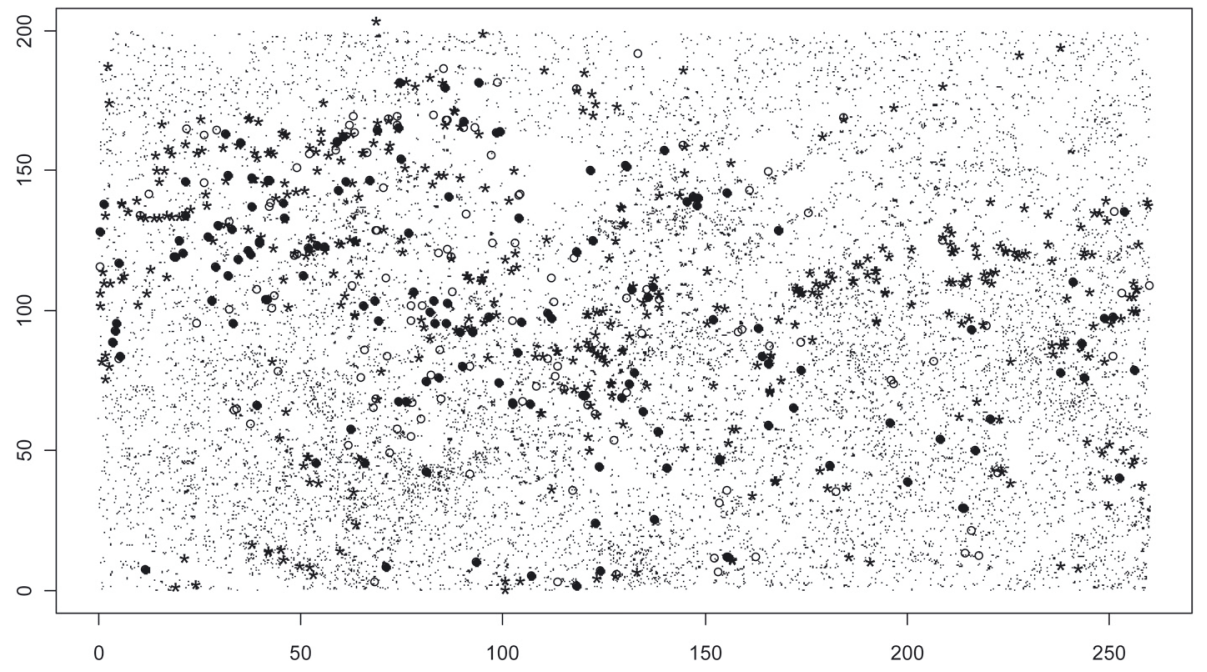

Figure 1. Spatial distribution of all live trees $>1 \mathrm{~cm} \mathrm{dbh}$ and their relative canopy positions to F. mandshurica trees in a 5.2 -hm ${ }^{2}$ plot $(260 \mathrm{~m} \times$ $200 \mathrm{~m})$. Solid and open circles represent female trees $(n=154)$ and male trees $(n=131)$ of $F$. mandshurica respectively; asterisks represent non-flowering trees $(n=487)$; and dots $(n=20177)$ represent other live trees $>1 \mathrm{~cm}$ dbh within research plot.

(WinSCANOPYTM 2003) on cloudless days in August 2005. The leaf area index (LAI) was computed using Bonhomme and Chartier's (1972) method, and assessed using the corresponding computer software WinSCANOPY and XLScanopy, and the average values of the two measurements were calculated for each subplot. Two soil samples were taken from the top $20 \mathrm{~cm}$ to analyze total nitrogen (the Kelvin Digestion method), total phosphorus (decomposing sodium carbonate method), total potassium (fusion with $\mathrm{NaOH}$ method), organic matter (exteriorly heating potassium dichromatedensity method) and soil $\mathrm{pH}$ in each $20 \mathrm{~m} \times 20 \mathrm{~m}$ subplot, and the average values were calculated for each subplot. All laboratory analyses were done according to the recommended procedures of the China Soil Council (1999). A hand-held soil moisture teller (HH2 DelLa-T Devices Moisture Meter, UK) was used to measure the volumetric soil moisture content at 0-20 cm depth in each subplot.
Over the 4-year period from 2005 to 2008 of this study, the sex of all reproductive $F$. mandshurica individuals with $\mathrm{dbh}>5 \mathrm{~cm}$ were determined by observing reproductive organs (flowers and/or seeds) through binoculars within the study area. The field observations were performed from April to October in 2005, 2006, 2007 and 2008. During the field observations, it was found that female $F$. mandshurica left behind numerous petioles of inflorescence on the stems, but males did not. Thus, females can be identified by the previous year's petioles of inflorescence on the stems when other reproductive organs are not visible. F. mandshurica trees were strictly dioecious and no sex switching (Zhan et al., 2005). Thus a cumulative sex expression was used in this research ${ }^{1}$. The gender of a few individuals could not be

\footnotetext{
${ }^{1}$ A cumulative sex expression is defined as the gender identification resulting from four independent assessments.
} 


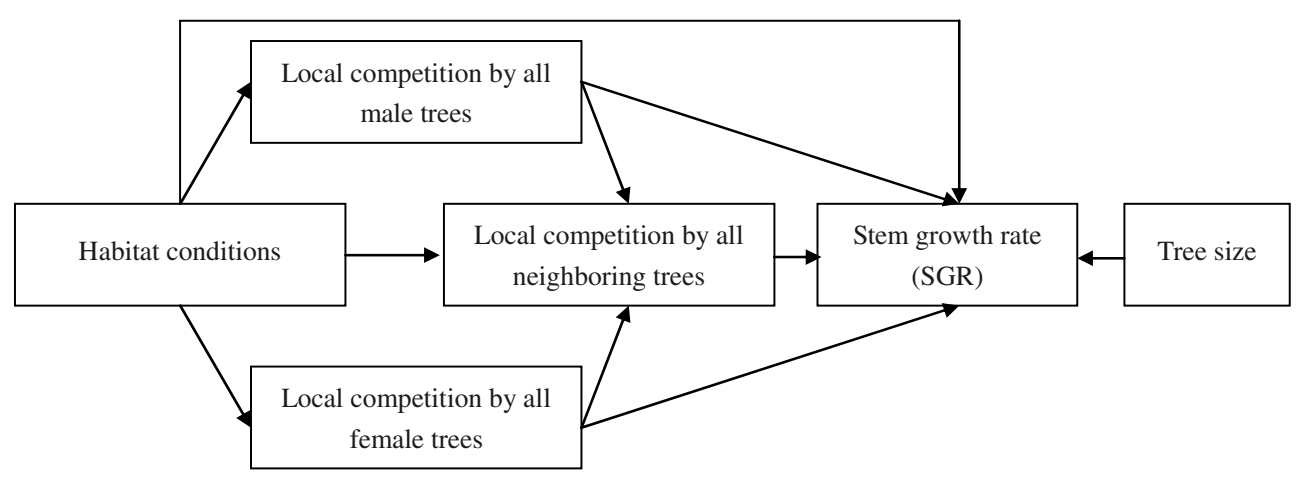

Figure 2. Path analysis diagram showing the influence of local competition from neighboring trees, tree size and environment factors on the growth rates of reproductive $F$. mandshurica. The single-directional arrows define the cause-and-effect relationships in the path diagram for the causal model. Residual errors associated with each endogenous variable in the model are not shown. Tree size is expressed as stem diameter at breast height measured in 2005. Stem growth rates are expressed as the radius increment at breast height from 2003 to 2007.

determined due to lacking reproductive organs during the observations. All dbh data used in this study were measured in 2005.

In order to estimate growth differences due to spatial and nutrient competition between the stems of the tree, two increment cores were extracted from the main trunk of each of the reproductive $F$. mandshurica trees at breast height and at the base $(15 \mathrm{~cm}$ above ground level) respectively. After surfacing and cross-dating, tree-ring widths of cores were measured at an accuracy of $0.01 \mathrm{~mm}$ using the Lintab5 in 2008. Possible dating or measurement errors were checked by the COFECHA program (Holmes, 1983). The radial growth of stems at breast height over the last 5 years (from 2003 to 2007) was defined as the stem growth rate of trees $(\mathrm{cm}$ per $5 \mathrm{y}$ ). The tree age was determined by tree-rings of the basal cores. A geometric method developed by Duncan (1989) was used to estimate the pith location when a partial core passed close to the pith. Finally, 258 reproductive trees were successfully cross-dated after eliminating rotten cores.

\subsection{Data analysis}

The analysis was performed using the statistical software $\mathrm{R}$ version 2.6.2. A two-way mixed-model ANOVA (analysis of variance) was carried out to evaluate the effects of sex and tree size on the growth of stem diameter at breast height. When the interaction term was significant, one-way ANOVA combining sex and tree size into one categorical variable was performed, and multiple comparisons with Bonferroni post hoc test were also performed to isolate these differences whenever a difference was detected. Stem growth rates were transformed to $x^{\prime}=x^{1 / 2}$ to meet the normality assumptions required in the ANOVAs.

Ripley's $K$-function was used to study the spatial distribution and spatial relationships. The univariate spatial pattern was analyzed using the $L(t)$ function $(L(t)=\sqrt{K(t) / \pi}-t)$, a transformation of Ripley's $K$-function (Ripley, 1981; Diggle, 1983). A Monte-Carlo simulation was used to test the statistical significance of deviations of $L(t)$ from zero under the null hypothesis of CSR (Besag \& Diggle, 1977). Ninety-five percent confidence intervals were generated using high and low values of $L(t)$ obtained from 10000 simulations of random permutations. Spatial relationships were analysed by Ripley's $L_{12}(t)$ function $\left(L_{12}(t)=\sqrt{K_{12}(t) / \pi}-t\right)$ of transformation of the Ripley's $K_{12}$-function (Diggle, 1983; Upton and Fingleton, 1985). The random labelling hypothesis was adopted to test the relationships between both genders, as suggested by Goreaud and Pélissier (2003).

The use of path analysis as a means of analyzing systems involving multiple causality has become increasingly prevalent recently. Path analysis was developed in the 1920 s by Wright $(1920,1934)$ to analyze systems of multiple causality. This method, which represents a useful extension of the regression approach, was used to analyze inter- and intrasexual effects of neighboring competition on the stem growth of flowering $F$. mandshurica. A causal relationship model was constructed separately for males and females. The stem growth rate was used as response variables. Tree size represented by stem dbh in 2005, neighboring competition and environment factors were used as predictor variables (refer to path diagram in Fig. 2).

Competition intensity from neighboring trees was computed using the Iterative Hegyi Index (Lee and Gadow, 1997).The Iterative Hegyi Index was calculated in three stages:

(1) Determine the dynamic radius of the competition zone: To illustrate the effect of neighborhood radius on the target trees, 10 neighborhood radii (distance from 1 to $10 \mathrm{~m}$, at $1 \mathrm{~m}$ intervals) were adopted to define the competition zone in this study.

(2) Select all active competitors within competition zone (CZ) with 10 neighborhood radii: Competitors have a big enough relative size, i.e., $d_{j}>0.3 d_{i}$ (where $d_{j}$ is the dbh of competitors, $d_{i}$ is the dbh of target trees); determining active competitors which are outside the shade of others $\left(\mathrm{CEA}=30^{\circ}\right)$.

(3) Calculate the iterative $\mathrm{HgCI}$ (Hegyi competition Index), $H g C I_{i}=\sum_{j=1}^{n} d_{j} /\left(d_{i} \times \operatorname{dist}_{i j}\right)$

where, $d$ is the diameter at breast height $(\mathrm{cm})$; dist is the horizontal distance between the reference tree and its neighbors $(\mathrm{m}) ; i$ refers reference trees; $j$ to neighboring trees.

\section{RESULTS}

\subsection{Sex ratio and age structure}

There are 154 females, 131 males and 267 non-flowering trees of adult $F$. mandshurica $(\mathrm{dbh}>5 \mathrm{~cm})$ within the 5.2-ha experimental area. The general sex ratio (male:female $=0.85$ ) did not significantly deviate from $1: 1\left(\chi^{2}=1.86\right.$, d.f. $=1, P=$ $0.17)$. Of the 285 flowering trees, 142 females and 116 males 


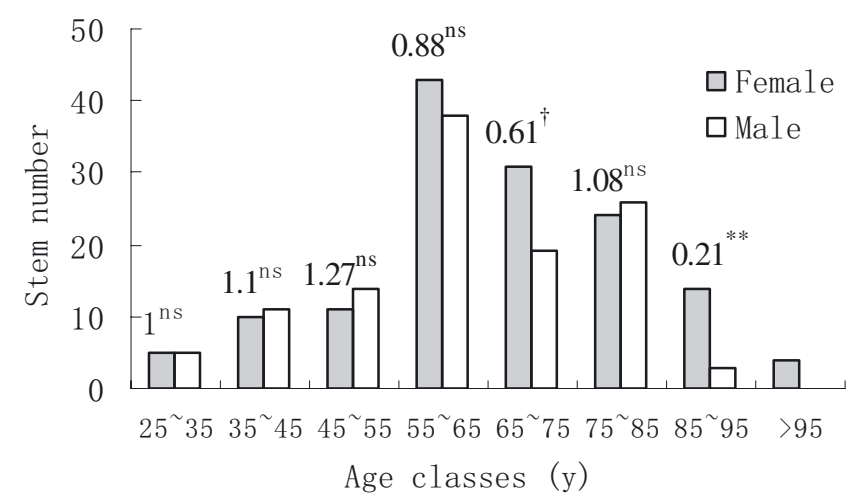

Figure 3. Age structure of male and female F. mandshurica trees. The distributions between genders had no significant difference according to Kolmogorov-Smirnov test $(P>0.05)$, with a greater proportion in the mid-age classes. The figures indicated the sex ratios (male:female), and the significance deviated from expected 1:1 was examined by chi-square test. $* * P<0.01$, $* P<0.05, \dagger 0.05<P<$ 0.1 , ns $P>0.1$.

were determined tree ages successfully. The sex ratio varied among age classes. The flowering $F$. mandshurica population exhibited a female-biased sex ratio in the 85-95 y age class $\left(\chi^{2}=7.12\right.$, d.f. $\left.=1, P=0.008\right)$. A female-biased sex ratio in the $65-75$ y age class was also detected, though only with a marginal significance $\left(\chi^{2}=2.88\right.$, d.f. $\left.=1, P=0.09\right)$. There was no difference in mean age between males and females $(66.75 \pm 1.51$ y for females, $63 \pm 1.35$ y for males; $t=1.813$, d.f. $=256, P=0.071)$. The age structure of male and female trees showed a similar distribution. Most of trees were concentrated in the middle range of age classes (55-85 y). The number of male and female trees peaked in the 55-65 age class, in which the stems of male and female accounted for $32.8 \%$ and $30.3 \%$ respectively. The maximum age of female trees was $146 \mathrm{y}$, but only 4 females were older than $95 \mathrm{y}$ - in 258 flowering trees (Fig. 3). As expected, the tree ages were correlated with dbhs (Males: $r=0.269, P<0.01$; Females: $r=0.365$, $P<0.01)$, and this relationships can be expressed by the model age $=1.1729 \mathrm{dbh}+37.6456\left(R^{2}=0.1332, P<0.0001\right)$ for females and age $=0.6062 \mathrm{dbh}+48.4708\left(R^{2}=0.07226\right.$, $P<0.01)$ for males.

\subsection{Sex differences in size-dependent stem growth}

A two-way ANOVA was used to determine the extent of differences in stem growth between sexes and among tree sizes. Stem diameter growth rates of males were different from those of females and the multiple comparison with a Bonferroni test showed that the growth rates differed significantly among tree size classes $(P<0.05)$. The results revealed that the growth rate was extremely sensitive to gender and tree size difference, as shown by a highly significant gender-related and sizedependent effect (Tab. II). The stem growth rate of male trees was greater than that of female trees $(P<0.01)$, and the stem growth rate also significantly increased with increasing tree size $(P<0.01)$.
Table II. Results of two-way ANOVA examining the effect of sex and tree size on the growth rates.

\begin{tabular}{lccccc}
\hline Source & d.f. & SS & MS & $F$-value & $P$-value \\
\hline Tree size $^{\mathrm{a}}$ & 1 & 5.9567 & 5.9567 & 152.2058 & $<0.001$ \\
Sex $^{\mathrm{b}}$ & 1 & 0.1771 & 0.1771 & 4.5265 & 0.0338 \\
Tree size $\times$ Sex $^{\mathrm{c}}$ & 1 & 0.4251 & 0.4251 & 10.8615 & 0.001 \\
Residuals & 540 & 21.1333 & 0.0391 & & \\
\hline
\end{tabular}

a Tree size was expressed as five dbh-categories as showed in Figure 4.

${ }^{\mathrm{b}}$ Sex included male plants and female plants.

${ }^{c}$ The interaction term between tree size and sex.

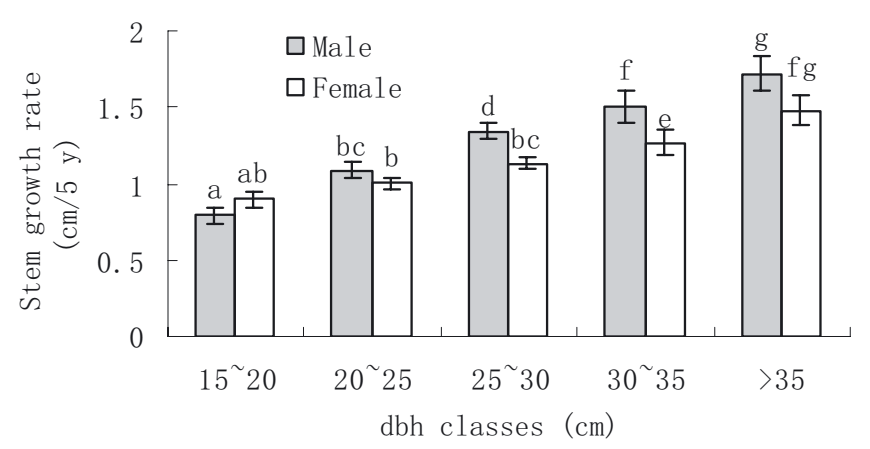

Figure 4. Stem growth rates (means $\pm 1 \mathrm{SE}$ ) of males and females in different dbh classes. Different letters above bars indicate significant difference between means at the 0.05 levels following sequential Bonferroni correction for multiple comparisons.

The difference of stem growth rates between genders varied among tree size classes. The stem growth rates of male trees are lower than those of female trees in the 15-20 cm dbh class, but larger in the other dbh classes. A statistically significan difference between genders was detected in the $25-30 \mathrm{~cm}$ and $30-35 \mathrm{~cm}$ dbh classes (Bonferroni correction for multiple comparisons, all $P<0.05$; Fig. 4).

The results in Table II indicate that the effect of tree size on the stem growth rates tended to differ within male trees and within female trees. And a significant interaction was found between tree size and gender (tree sizexsex interaction term, $P<0.05$; see Tab. II).

\subsection{The effects of intrasexual competition on stem growth}

The spatial distribution was analysed using Ripley's $L$-function. An univariate analysis produced values of $L(t)$ above the upper confidence interval (Figs. 5a, b), which indicates a clumped distribution of males and females at all studied scales. A bivariate analysis exhibited spatial segregation between males and females at small scales (1-6 m scales) under the random labelling null hypothesis (Fig. 5c).

A forward selection with 999 permutation iterations under the reduced model were used to eliminate all non-significant habitat effects on stem growth $(P<0.05)$. Finally, only soil moisture was retained as habitat factor for the ensuing path analysis. The path analysis revealed that stem growth rates 

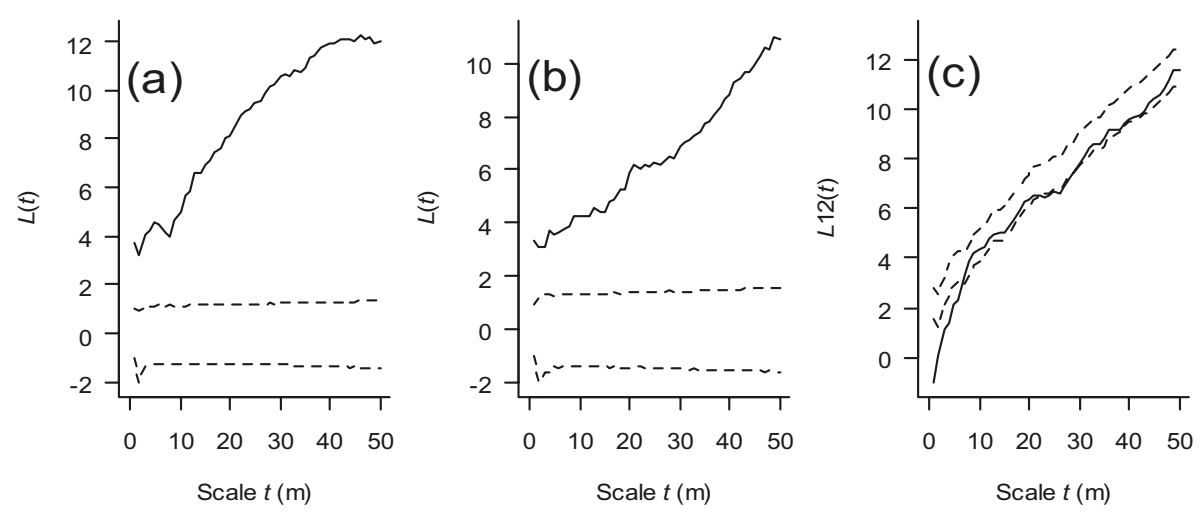

Figure 5. (a) Spatial distribution of female trees; (b) Spatial distribution of male trees; (c) Spatial relationships between males and females. Solid lines indicate plots of $L(t) / L_{12}(t)$ versus scale $t$; dashed indicate $95 \%$ confidence intervals.

were positively affected by soil moisture and tree size for both genders at all considered neighborhood radii. This confirms that stem growth significantly increases with increasing soil moisture and tree size. The growth rates of female trees were negatively affected by neighboring competition from other female trees at all neighborhood radii between 1 and $10 \mathrm{~m}$, but were not significantly affected by male trees and other trees. The growth rates of male trees were negatively affected by other competing male trees at neighborhood radii of 3-10 m. However, the growth rates of male trees were not significantly affected by competing female trees and other trees. Neighboring competition by all trees around reference trees did not affect the stem growth rates of both genders at all considered neighborhood radii (Tab. III).

\section{DISCUSSION}

\subsection{Sex ratios and age structure}

Our research revealed that the sex ratio varied among age classes. Male:Female sex ratios are larger than one in young flowering trees $(25-55 \mathrm{y})$, which means that male trees are dominant in the younger age classes. Females, on the other hand, showed a dominance in old flowering trees $(>55 \mathrm{y})$, especially in the 65-75 and 85-95 y age classes, where a significant female-biased sex ratio is observed. The experiment belongs to an early successional stage of a forest community on a dry site. Soil water deficits may affect the survival of male F. mandshurica trees. Male trees showed a higher mortality than female trees, especially, in the old age classes. However, mortality data are insufficient to examine this aspect in depth. At this stage, our hypothesis is a reasonable one, and will be investigated in a subsequent study. The sex ratio pattern was induced by a gender-specific growth pattern. The age class distribution of the flowering F. mandshurica population was skewed with a high frequency of middle- and larger ages, suggesting that future recruitment may be severely affected under current structural conditions.

\subsection{Intersexual differences in size-dependent growth rates}

Previous research has shown that males of dioecious plants show higher growth rates than females. Retuerto et al. (2000) reported that female plants exhibited significantly greater relative diameter growth rates than male plants in the dioecious tree Ilex aquifolium. Cornelissen and Stiling (2005) reported better growth rates of male plants plants in 33 independent studies. Our results are consistent with these findings and those of Jing and Coley (1990), Krischik and Denno (1990) and Gauquelin et al. (2002). We found that male trees exhibited faster stem growth than female trees within the flowering F. mandshurica population. According to assumptions regarding the trade-offs between reproductive and vegetative processes, the observed slower growth of females might be attributed to the greater outlay on reproduction (Obeso, 1997; Obeso et al., 1998). Female trees produce fruits and seeds that require considerable investments in energy, biomass and nutrients, and may explain the reduced stem growth of females.

As plant size increases, the trade off between reproduction and vegetative growth may differ for males and females (Antos and Allen, 1999; Delph, 1999; Korpelainen, 1992; Pickering, 2000). For example, selection for increased floral display in males with increasing size may not result in the same proportional increase in biomass allocated to reproduction as it would for females (Pickering and Arthur, 2003). When a sizestratified sample of $F$. mandshurica trees was analyzed, the stem growth was found to be size-dependent for both males and females (Tab. II). The causal model shows that the value of the path coefficient of the tree size effect on stem growth was over 0.30 and 0.43 for females and males respectively (Tab. III). Taken together, our findings agreed with those of Bullock (1992) who suggested that tree size significantly effects growth in a dioecious species.

\subsection{The effects of intrasexual competition on stem growth}

Growth is primarily limited by habitat factors, such as moisture availability or soil nutrient levels (Antos and Allen, 1999). 
Table III. Path coefficients for the effects of tree size, neighboring competition and habitat factor on stem growth rate (SGR) for both genders at 10 neighborhood radii.

\begin{tabular}{|c|c|c|c|c|c|}
\hline \multirow{2}{*}{ Cause-effect relationships } & \multicolumn{5}{|c|}{ Competition zone radius } \\
\hline & $r=9-10 \mathrm{~m}$ & $r=5-8 \mathrm{~m}$ & $r=4 \mathrm{~m}$ & $r=3 \mathrm{~m}$ & $r=1-2 \mathrm{~m}$ \\
\hline \multicolumn{6}{|l|}{ Female plants } \\
\hline Soil moisture $\rightarrow$ Neighboring competition by all trees & -0.04 & -0.04 & -0.04 & -0.04 & {$[-0.06,-0.05]$} \\
\hline Soil moisture $\rightarrow$ Neighboring competition by males & {$[-0.25,-0.24]^{*}$} & {$[-0.23,-0.19]^{*}$} & $-0.20^{*}$ & -0.16 & -0.11 \\
\hline Soil moisture $\rightarrow$ Neighboring competition by females & -0.07 & -0.07 & -0.07 & -0.07 & {$[-0.06,-0.05]$} \\
\hline Soil moisture $\rightarrow$ SGR & $0.29^{* *}$ & {$[0.29,0.31]^{* *}$} & $0.32^{* * *}$ & $0.32^{* * *}$ & $0.32^{* * *}$ \\
\hline Neighboring competition by all trees $\rightarrow$ SGR & {$[0.17,0.18]$} & {$[0.18,0.21]$} & 0.23 & 0.28 & {$[0.22,0.24]$} \\
\hline Neighboring competition by males $\rightarrow$ SGR & -0.09 & {$[-0.01,-0.09]$} & 0.06 & 0.01 & 0.03 \\
\hline Neighboring competition by females $\rightarrow$ SGR & {$[-0.19,-0.18]^{*}$} & {$[-0.23,-0.20]^{*}$} & $-0.24^{*}$ & $-0.29^{*}$ & {$[-0.25,-0.22]^{*}$} \\
\hline Tree size $\rightarrow$ SGR & $0.30^{* * *}$ & {$[0.30,0.31]^{* * *}$} & $0.31^{* * *}$ & $0.32^{* * *}$ & {$[0.31,0.32]^{* * *}$} \\
\hline Neighboring competition by females $\rightarrow$ Neighboring competition by all trees & $0.88^{* * *}$ & {$[0.88,0.90]^{* * *}$} & $0.90^{* * *}$ & $0.92^{* * *}$ & {$[0.84,0.87]^{* * *}$} \\
\hline $\begin{array}{l}\text { Neighboring competition by males } \rightarrow \text { Neighboring competition by all trees } \\
\text { Male plants }\end{array}$ & {$[-0.02,-0.01]$} & {$[-0.02,-0.01]$} & -0.01 & 0.01 & {$[-0.025,0]$} \\
\hline Soil moisture $\rightarrow$ Neighboring competition by all trees & 0.06 & 0.06 & 0.058 & 0.059 & 0.05 \\
\hline Soil moisture $\rightarrow$ Neighboring competition by males & {$[-0.17,-0.15]$} & {$[-0.19,-0.11]$} & -0.15 & -0.134 & {$[-0.11,0]$} \\
\hline Soil moisture $\rightarrow$ Neighboring competition by females & -0.04 & -0.04 & -0.035 & -0.035 & {$[-0.04,-0.03]$} \\
\hline Soil moisture $\rightarrow$ SGR & $0.23^{* *}$ & {$[0.23,0.25]^{* *}$} & $0.239^{* *}$ & $0.241^{* *}$ & $0.26^{* *}$ \\
\hline Neighboring competition by all trees $\rightarrow$ SGR & {$[-0.09,-0.08]$} & {$[-0.09,-0.08]$} & -0.085 & -0.076 & -0.09 \\
\hline Neighboring competition by males $\rightarrow$ SGR & {$[-0.25,-0.22]^{* *}$} & {$[-0.21,-0.16]^{*}$} & $-0.162^{*}$ & $-0.157^{*}$ & {$[-0.06,0]$} \\
\hline Neighboring competition by females $\rightarrow$ SGR & {$[-0.07,-0.06]$} & {$[-0.07,-0.06]$} & -0.058 & -0.075 & -0.05 \\
\hline Tree size $\rightarrow$ SGR & {$[0.43,0.44]^{* * *}$} & {$[0.44,0.46]^{* * *}$} & $0.466^{* * *}$ & $0.464^{* * *}$ & $0.49^{* * *}$ \\
\hline Neighboring competition by females $\rightarrow$ Neighboring competition by all trees & $0.80^{* * *}$ & $0.80^{* * *}$ & $0.794^{* * *}$ & $0.798^{* * *}$ & $0.79^{* * *}$ \\
\hline Neighboring competition by males $\rightarrow$ Neighboring competition by all trees & 0.01 & {$[0,0.03]$} & 0.024 & 0.043 & {$[-0.03,0]$} \\
\hline
\end{tabular}

Tree size was presented by dbh in 2005; Stem growth rate (SGR, cm/5 years) was calculated with radius increment at breast height from 2003 to 2007. The figures in the square brackets refer to the range of the path coefficient. The path coefficient describes the estimated strength of effects between variables. Larger absolute values of the path coefficient indicate higher strength. The positive and negative signs indicate positive and negative causality respectively. $* P<0.05 * * P<0.01 * * * P<0.001$.

In our study, neighboring competition by males suffered negative influence from soil moisture around female $F$. mandshurica trees (Tab. III), which suggests some stress induced by competition for soil water between genders. Gender-specific efficiency in water use could play a decisive role in explaining such gender-related differences in growth and ecological interactions (Callaway et al., 1996; Collet et al., 1996; Retuerto et al., 2000). The stem growth rate was significantly enhanced by increasing of soil moisture for both genders in flowering F. mandshurica trees (Tab. III), and we conclude that sexual differences in growth rates can be partly explained by the availability of soil water.

Nanami et al. (2005) argued that both intra- and intersexual effects of neighbors on growth rates were significant for female Podocarpus nagi trees, but neither was significant for males, thus females may be more sensitive than males to the presence of neighbors because of a higher reproductive cost than males. Our study showed that intrasexual competition (male-male competition and female-female competition) had a negative and significant influence on stem growth for both genders. Strong effect of intrasexual competition on the stem growth can be interpreted mostly by the relative crown positions between both genders and other live trees' positions relative to $F$. mandshurica trees. A clumped distribution for each gender can be found in the research plot (Figs. 5a, 5b). The spatial segregation between genders, which was observed in the study plot (Fig. 5c), reduces competition between individ- uals of the opposite sex. Such sexual niche partitioning can be promoted if male fitness and female fitness respond differently across small scale environments. Lloyd and Webb (1977) and Cox (1981) have shown that the two sexes of dioecious trees respond differently to a given set of environmental conditions. Trees of the same sex usually have similar demands for specific environmental conditions, and this will induce competition for resources among them. The relative density of $F$. mandshurica is low in the research plot, which accounts for only $8.44 \%$ of total stems $>4 \mathrm{~cm}$ dbh (Tab. I). Although other live trees have absolute dominance in the stand, it tends to have more same sexual neighbors around the target trees due to the clumped distribution of each gender and spatial segregation between genders. Thus, this gender-related spatial distribution and spatial segregation between genders should be responsible for strong intrasexual competition effects on stem growth. As far as we know, our study is the first one which demonstrates that intrasexual competition within males and/or females is ultimately responsible for difference in stem growth for both genders. Those intersexual differences in the sensitivity to neighboring trees are an important driving force, influencing gender-specific growth patterns.

Some studies showed that the effects of neighboring competition could vary potentially depending on the neighborhood radius used to define the local competition zone (He and Duncan, 2000; Nanami et al., 2005; Peterson and Squiers, 1995). Our research is consistent with these findings. For 
example, the effect of neighboring competition by males on the stem growth of neighboring males varied among varying competition zone radii. The absolute value of the path coefficient increased with increasing competition zone radius, and the coefficients are significant for $2-10 \mathrm{~m}$ radii, but not for $r=1 \mathrm{~m}$ neighbor radius (Tab. III). These results suggest a dynamic sensitivity to neighbors depending on the competition zone radius.

Acknowledgements: We thank two anonymous referees for their constructive comments. This work was in part funded by 11th five-year National Science and Technology plan of China (Project 2006BAD03A0804), Beijing municipal commission of education (2007-2), and the National Natural Science Foundation of China (Project 30771716).

\section{REFERENCES}

Allen G.A. and Antos J.A., 1998. Relative reproductive effort in males and females of the dioecious shrub Oemleria cerasiformis. Oecologia 76: 111-118.

Allen G.A. and Antos J.A., 1993. Sex ratio variation in the dioecious shrub Oemleria cerasiformis. Am. Nat. 141: 537-553.

Antos J.A. and Allen G.A., 1999. Patterns of reproductive effort in male and female shrubs of Oemleria cerasiformis: A 6-year study. J. Ecol. 87: $77-84$.

Armstrong J.E. and Irvine A.K., 1989. Flowering, sex ratios, pollen-ovule ratios, fruit set, and reproductive effort of a dioecious tress, Myristica insipida (Myristicaceae), in two different rain forest communities. Am. J. Bot. 76: 74-85.

Barrett S.C.H. and Helenurm K., 1981. Floral sex ratios and lifehistory in Aralia nudicaulis (Araliaceae). Evolution 35: 752-62.

Besag J.E. and Diggle P.J., 1977. Simple Monte Carlo tests for spatial pattern. Appl. Stat. 26: 327-333.

Bonhomme R. and Chartier P., 1972. The interpretation and automatic measurement of hemispherical photographs to obtain sunlit folige area and gap frequency. Isr. J. Agric. Res. 22: 53-61.

Bullock S.H., 1992. Effects of sex, size and substrate on growth and mortality of trees in tropical wet forest. Oecologia 91: 52-55.

Callaway R.M., DeLucia E.H., Moore D., Nowak R., and Schlesinger W.H., 1996. Competition and facilitation: contrasting effects of Artemisia tridentata on desert vs. montane pines. Ecology 77: 21302141.

China Soil Council, 1999. Soil agricultural chemical analysis procedure, Chinese Agricultural Science Press, Beijing.

Cipollini M.L. and Stiles E.W., 1991. Costs of reproduction in Nyssa sylvatica: sexual dimorphism in reproductive frequency and nutrient flux. Oecologia 86: 585-593.

Cipollini M.L. and Whigham D.F., 1994. Sexual dimorphism and cost of reproduction in the dioecious shrub Lindera benzoin (Lauraceae). Am. J. Bot. 81: 65-75.

Collet C., Guehl J.M., Frochot H., and Ferhi A., 1996. Effect of two grasses differing in their growth dynamics on the water relations and the growth of Quercus petraea seedlings. Can. J. Bot. 74: 1562-1571.

Cornelissen T. and Stiling P., 2005. Sex-biased herbivory: a meta-analysis of the effects of gender on plant-herbivore interactions. Oikos 111: $488-500$

Cox P.A., 1981. Niche partitioning between sexes of dioecious plants. Am. Nat. 117: 295-307.

Davidson C.G. and Remphrey W.R., 1990. An analysis of architectural parameters of male and female Fraxinus pennsylvanica in relation to crown shape and crown location. Can. J. Bot. 68: 2035-2043.
Dawson T.E. and Ehleringer J.R., 1993. Gender-specific physiology, carbon isotope discrimination, and habitat distribution in box elder, Acer negundo. Ecology 74: 798-815.

Delph L.F., 1999. Sexual dimorphism in live history. In: Geber M.A., Dawson T.E., Delph L.F. (Eds.), Gender and sexual dimorphism in flowering plants, Springer-Verlag, Berlin, pp. 149-173.

Diggle P.J., 1983. Statistical analysis of spatial point patterns, Academic Press, London.

Duncan R., 1989. An evaluation of errors in tree age estimates based on increment cores in kahikatea (Dacrycarpus dacrydioides). N. Z. Nat. Sci. 16: 31-37.

Garcia M.B. and Antor R.J., 1995. Sex ratio and sexual dimorphism in the dioecious Borderea pyrenaica (Dioscoreaceae). Oecologia 101: 59-67.

Gauquelin T., Bertaudière-Montès V., Badri W., and Montès N., 2002. Sex ratio and sexual dimorphism in mountain dioecious thuriferous juniper (Juniperus thurifera L., Cupressaceae). Bot. J. Linn. Soc. 138: $237-244$.

Gehring J.L. and Linhart Y.B., 1993. Sexual dimorphisms and response to low resources in the dioecious plant Silene latifolia (Caryophyllaceae). Int. J. Plant Sci. 154: 152-162.

Goreaud F. and Pélissier R., 2003. Avoiding misinterpretation of biotic interaction with the intertype $\mathrm{K}_{12}$-function: population independence vs. random labeling hypotheses. J. Veg. Sci. 14: 681-692.

Grant M.C. and Mitton J.B., 1979. Elevational gradients in adult sex ratios and sexual differentiation in vegetative growth rates in Populus tremuloides Michx. Evolution 33: 914-918.

Gross K.L. and Soule J.D., 1981. Differences in biomass allocation to reproductive and vegetative structures of male and females plants of a dioecious, perennial herb, Silene alba (Miller) Krause. Am. J. Bot. 68: 801-807.

Guillon J.M. and Fievet D., 2003. Environmental sex determination in response to light and biased sex ratios in Equisetum gametophytes. J. Ecol. 91: 49-57.

He F. and Duncan R.P., 2000. Density-dependent effects on tree survival in an old-growth Douglas fir forest. J. Ecol. 88: 676-688.

Herrera C.M., 1988. Plant size, spacing patterns, and host plant selection in Osyris quadripartita, a hemiparasitic dioecious shrub. J. Ecol. 76: 995-1006.

Hill P.W., Handley L.L., and Raven J.A., 1996. Juniperus communis L. spp. communis at Balnaguard, Scotland: foliar carbon discrimination $\left(13^{\mathrm{C}}\right)$ and $15-\mathrm{N}$ natural abundance $\left(15^{\mathrm{N}}\right)$ suggest gender-linked differences in water and $\mathrm{N}$ use. Bot. J. Scotland 48: 209-224.

Hoffmann A.J. and Alliende M.C., 1984. Interactions in the patterns of vegetative growth and reproduction in woody dioecious plants. Oecologia 61: 109-114.

Holmes R.L., 1983. Computer-assisted quality control in tree-ring dating and measurement. Tree-Ring Bull. 44: 69-75.

Houle G. and Duchesne M., 1999. The spatial pattern of a Juniperus communis var. depressa population on a continental dune in subarctic Québec. Canada. Can. J. For. Res. 29: 446-450.

Houssard C., Thompson J.D., and Escarre J., 1994. Do sex related differences in response to environmental variation influence the sex ratio in the dioecious Rumex acetosella. Oikos 70: 80-90.

Jing S.W. and Coley P.D., 1990. Dioecy and herbivory: the effect of growth rate on plant defense in Acer negundo. Oikos 58: 369-377.

Kohorn L.U., 1994. Shoot morphology and reproduction in Jojoba: advantages of sexual dimorphism. Ecology 75: 2384-2394.

Korpelainen H., 1992. Patterns of resource allocation in male and female plants of Rumex acetosa and R. acetosella. Oecologia 89: 133-139.

Krischik V.A. and Denno R.F., 1990. Patterns of growth, reproduction, defense, and herbivory in the dioecious shrub Baccharis halimifolia (Compositae). Oecologia 83: 182-190. 
Lee W.K. and Gadow K.V., 1997. Iterative Bestimmung der Konkurrenzbäume in Pinus densiflora Beständen. Allg. ForstJagdztg: 168(3/4): 41-44.

Lee W.K., Gadow K.V., Chung D.J., Lee J.L., and Shin M.Y. 2003. DBH growth model for Pinus densiflora and Quercus variabilis mixed forests in central Korea. Ecol. Mod. 176: 187-200.

Lloyd D.G. and Webb C.J., 1977. Secondary sex characteristics in plants. Bot. Rev. 43: 177-216.

Lovett Doust J., O' Brien G., and Lovett Doust L., 1987. Effects of density on the secondary sex characteristics and sex ratio in Silene alba (Caryophyllaceae). Am. J. Bot. 74: 40-46.

Lovett-Doust J. and Lovett-Doust L., 1988. Modules of production and reproduction in a dioecious clonal shrub, Rhus typhina. Ecology 69: $741-750$.

Luken J.O., 1987. Interactions between seed production and vegetative growth in staghorn sumac, Rhus typhina. Bull. Torr. Bot. Club. 114: 247-251.

Marion C. and Houle G., 1996. No differential consequences of reproduction according to sex in Juniperus communis var. depressa (Cupressaceae). Am. J. Bot. 83: 480-488.

Meagher T.R. and Antonovics J., 1982. The population biology of Chamaelirium luteum, a dioecious member of the lily family: life history studies. Ecology 63: 1690-1700.

Nanami S., Kawaguchi H., and Yamakura T., 2005. Sex ratio and genderdependent neighboring effects in Podocarpus nagi, a dioecious tree. Plant Ecol. 177: 209-222.

Nicotra A.B., 1999. Sexually dimorphic growth in the dioecious tropical shrub, Siparuna grandiflora. Funct. Ecol. 13: 322-331.

Obeso J.R., Alvarez-Santullano M., and Retuerto R., 1998. Sex ratios, size distributions, and sexual dimorphism in the dioecious tree Ilex aquifolium (Aquifoliaceae). Am. J. Bot. 85: 1602-1608.

Obeso J.R., 1997. Costs of reproduction in Ilex aquifolium: effects at tree, 1-year shoot and leaf levels. J. Ecol. 85: 159-166.

Obeso J.R., 2002. The costs of reproduction in plants. New Phytol. 155: $321-348$

Onyekwelu S.S. and Harper J.L., 1979. Sex ratio and niche differentiation in spinach (Spinacia oleracea L.). Nature 282: 609-611.

Peterson C.J., and Squiers E.R., 1995. Competition and succession in an aspen-white-pine forest. J. Ecol. 83: 449-457.

Pickering C.M. and Arthur J.M., 2003. Patterns of resource allocation in the dioecious alpine herb Aciphylla simplicifolia (Apiaceae). Austral Ecol. 28: 566-574.
Pickering C.M., 2000. Sex-specific differences in floral display and resource allocation in Australian alpine dioecious Aciphylla glacialis (Apiaceae). Aust. J. Bot. 48: 81-91.

Popp J.W. and Reinartz J.A., 1988. Sexual dimorphism in biomass allocation and clonal growth of Xanthoxylum americamum. Am. J. Bot. 75: $1732-1741$.

Putwain P.D. and Harper J.L., 1972. Studies in the dynamics of plant populations. V. Mechanisms governing the sex ratios in Rumex acetosa and $R$. acetosella. J. Ecol. 60: 113-129.

Ramadan A., El-Keblawy A., Shaltout K., and Lovett Doust J., 1994. Sexual polymorphism, growth, and reproductive effort in Egyptian Thymelaea hirsute (Thymelaeaceae). Am. J. Bot. 81: 847-857.

Ramp P.F. and Stephenson S.N., 1988. Gender dimorphism in growth and mass partitioning by box-elder (Acer negundo L.). Am. Midl. Nat. 119: 420-430.

Retuerto R., Lema B.F., Roiloa S.R., and Obeso J.R., 2000. Gender, light and water effects in carbon isotope discrimination, and growth rates in the dioecious tree Ilex aquifolium. Funct. Ecol. 14: 529-537.

Ripley B.D., 1981. Spatial statistics. John Wiley, New York.

Rocheleau A.F. and Houle G., 2001. Different cost of reproduction for the males and females of the rare dioecious shrub Corema conradii (Empetraceae). Am. J. Bot. 88: 659-666.

Sakai A. and Burris T., 1985. Growth in male and female aspen clones: a 25-year longitudinal study. Ecology 66: 1921-1927.

Sakai A.K. and Sharik T.L., 1988. Clonal growth of male and female Bigtooth Aspen (Populus grandidentata). Ecology 69: 2031-2033.

Tryon E.H. and Pease R.W., 1953. Shading effects of natural canopies on holly characteristics. Castanea 18: 70-83.

Upton G. and Fingleton B., 1985. Spatial data analysis by example. Vol. 1. point pattern and quantitative data. John Wiley, New York.

Vasiliauskas S.A. and Aarssen L.W., 1992. Sex ratio and neighbor effects in monospecific stands of Juniperus virginiana. Ecology 73: 622632.

Willson M.F., 1986. On the cost of reproduction in plants: Acer negundo. Am. Midl. Nat. 115: 204-207.

Wright S., 1920. The relative importance of heredity and environment in determining the piebald pattern of guinea pigs. Proc. Natl. Acad. Sci. 6: $320-332$.

Wright S., 1934. The method of path coefficients. Ann. Math. Stat. 5: 161-215.

Zhan Y.G., Yin L.H., Liu X.M., Zhang G.Q., 2005. Development of macrospore and microspore, male and female gametophytes of Fraxinus mandshurica Rupr. and its phylogenetic significance. Int. J. Automation Comp. 27: 42-47. 